\title{
SIKAP PETANI PADI TERHADAP BENIH UNGGUL PADI BERSERTIFIKAT DI KECAMATAN KARANGPANDAN, KABUPATEN KARANGANYAR
}

\author{
Nurul Fajri Mayalibit*, Suwarto, Eksa Rusdiyana dan Arip Wijianto \\ Program Studi Penyuluhan dan Komunikasi Pertanian, Fakultas Pertanian, Universitas Sebelas Maret \\ *Corresponding author: nfmayalibit@gmail.com
}

\begin{abstract}
This research to analyze the attitude of farmers against rice seed certified, analyze the factors forming attitudes, analyze the relationships between the factors forming the attitude with the attitude of farmers, as well as analyzing the difference in the attitude of farmers. This study determined the location intentionally (purposive) in Karangpandan Subdistrict, Karanganyar District. Using multi-stage random cluster sampling. The data are classified using the width of the interval. To find out the relationship between the factors forming the attitude with the attitude of farmers rice against the rice seed certified used Spearman Rank correlation test ( $r$ s). To know the difference in the attitude of farmers used Wilcoxon test using a computer program SPSS 16.0 for windows. The results showed that the respondent's age category high, formal education category low, personal experience category medium, the influence of other people considered important category very high, and the influence of the mass media categories medium. The attitude of farmers against Seed Certified Padi 56.67\%, farmers very agree rice certified seed. Rank Spearman correlation test based on 95\% confidence level indicates that the relationship was not significant between age and the influence of mass media with the attitude of farmers rice against the rice seed certified. The significant relationship between formal education with the attitude of farmers rice against the rice seed certified. While personal experience has a very significant relationship but in the opposite direction and influence others who are considered essential to have a very significant relationship in one direction with the attitude of farmers against rice seed certified.
\end{abstract}

Keywords: Certified; Demeanor; Paddy; Seed; Superior

Cite this as: Mayalibit, N., Suwarto, S., Rusdiyana, E., \& Wijianto, A. 2017. Sikap Petani Padi terhadap Benih Unggul Padi Bersertifikat di Kecamatan Karangpandan, Kabupaten Karanganyar. Caraka Tani: Journal of Sustainable Agriculture. 32(2), 116-125. doi: http://dx.doi.org/10.20961/carakatani.v32i2.15090

\section{PENDAHULUAN}

Kebijakan pemerintah pada pembangunan bidang pertanian khususnya tanaman pangan bertujuan untuk melestarikan swasembada beras, swasembada jagung, kedelai dan tanaman pangan lainnya. Untuk mencapai tujuan ini diperlukan dukungan terkait ketersediaan benih bermutu dari varietas unggul yang memadai baik kualitas maupun kuantitasnya. Menurut Justice dan Bass (2004), ketersediaan benih yang bermutu tinggi merupakan salah satu kunci keberhasilan usaha di bidang pertanian. Ketersediaan benih tepat waktu, tepat jumlah, tepat harga, tepat mutu, tepat lokasi dan tepat varietas masih menjadi kendala ditingkat petani, sehingga mengakibatkan pengguna benih bermutu masih sangat terbatas atau sedikit. Untuk memperoleh benih yang baik tidak terlepas dari suatu rangkaian kegiatan teknologi benih yaitu mulai dari produksi benih, pengolahan benih, pengujian benih, sertifikasi benih sampai penyimpanan benih. Sertifikasi benih bertujuan untuk memberikan jaminan bagi pembeli benih (petani) tentang beberapa aspek mutu yang penting (fisik-fisiologis dan identitas genetik) yang tidak dapat ditentukan dengan segera, dengan hanya memeriksa benihnya saja. Sertifikasi dilaksanakan pada (1) sumber benih untuk menjamin kebenaran klasifikasi sumber benih, (2) mutu benih dan/atau bibit secara fisikfisiologis dan genetik.

Selama ini sertifikat/label yang dikeluarkan oleh Balai Pengawasan dan Sertifikasi Benih (BPSB) dijadikan jaminan tingkat kualitas benih padi. Oleh karena itu, ketersediaan benih padi bersertifikat/berlabel dalam jumlah yang 
memadai merupakan syarat utama. Luas tanam padi di Jawa Tengah sekitar 1.750 .000 ha/tahun. Asumsinya adalah volume benih rata-rata 26 $\mathrm{kg} / \mathrm{ha}$, maka total benih padi varietas unggul bersertifikat Jawa Tengah yang dibutuhkan diperkirakan lebih dari 40.000 ton permusim tanam. Sejalan dengan upaya-upaya percepatan produksi benih berlabel yang telah dilakukan, pada tahun 2009 produksi benih padi berlabel produsen benih padi di Jawa Tengah mencapai 46.661 ton, sementara itu rencana indikatif kebutuhan benih MT 2009/2010 sejumlah 43.249 ton. Total produksi benih padi bersertifikat tersebut sebagian besar adalah varietas Ciherang $(48,70 \%)$, IR-64 $(29,36 \%)$ dan $(22 \%)$ berupa benih varietas unggul lainnya.

Benih di Indonesia memiliki beberapa masalah, masalah paling utama yang sering terjadi yaitu mengenai kualitas benih. Pada sebuah kabupaten di Jawa Barat, benih padi berlabel yang banyak beredar di pasaran ternyata tidak diminati oleh petani. Mereka beralasan takut menggunakan benih berlabel karena pernah mengikuti anjuran/penyuluhan penggunaan bibit berlabel, namun setelah dicoba ternyata benihnya tidak tumbuh. Hasilnya mereka lebih suka menggunakan benih lokal (Sodikin, 2015). Sama halnya di Jawa Barat, Jawa Tengah walaupun sistem manajemen mutu perbanyakan benih bersertifikat telah banyak ditetapkan, namun pada kenyataanya sistem pembenihan di Jawa Tengah masih dijumpai beberapa masalah antara lain: 1) keterbatasan informasi ketersediaan benih sumber, 2) adanya kecenderungan produsen benih hanya memproduksi benih varietas yang popular saja, 3) manajemen enam tepat yang meliputi tepat, varietas, jumlah, waktu, lokasi dan harga masih belum terpenuhi, 4) kinerja kelembagaan perbenihan belum optimal, serta 5) benih bermutu/bersertifikasi belum semuanya terdistribusi kepada petani pengguna (Prasetyo dan Setiani, 2011). Melihat masalah-masalah yang pernah ada sehingga menarik untuk dilakukan pengkajian tentang Sikap Petani Padi Terhadap Benih Unggul Padi Bersertifikat Di Kecamatan Karangpanan, Kabupaten Karanganyar.

Berdasarkan uraian diatas, maka tujuan dilakukan penelitian ini adalah sebagai berikut: 1 ) Menganalisis sikap petani padi terhadap benih unggul padi bersertifikat di Kecamatan Karangpandan, Kabupaten Karanganyar. 2) Mengkaji faktor-faktor yang membentuk sikap petani padi terhadap benih unggul padi bersertifikat di Kecamatan Karangpandan, Kabupaten Karanganyar. (3) Mengetahui hubungan antara faktor-faktor yang membentuk sikap dengan sikap petani padi terhadap benih unggul padi bersertifikat di Kecamatan Karangpandan, Kabupaten Karanganyar. (4) Menganalisis perbedaan sikap petani padi terhadap benih unggul padi bersertifikat berdasarkan jarak desa yang jauh dan jarak desa yang dekat dengan Balai Benih Padi di Kecamatan Karangpandan, Kabupaten Karanganyar.

\section{METODE PENELITIAN}

Metode dasar penelitian yang digunakan dalam penelitian ini adalah metode penelitian kuantitatif. Teknik pelaksanaan penelitian ini menggunakan teknik survei. Penentuan lokasi penelitian dilakukan secara purposive. Penelitian ini dilakukan di Kabupaten Karanganyar hal ini dikarenakan Kabupaten Karanganyar merupakan salah satu kabupaten yang memiliki Balai Benih Padi yang menyediakan benih bersertifikat yang cukup banyak yaitu 5 (lima) lokasi antara lain Watusambang (Tawangmangu), Jumantono, Jumapolo, Karangpandan dan Jenawi. Terdapat 5 (lima) balai benih padi di Kabupaten Karanganyar, akan tetapi balai benih padi paling besar yang menyediakan benih unggul padi besertifikat sepanjang tahun adalah Karangpandan. Namun pada kenyataannya menurut Balai Pengawasan dan Sertifikasi Benih petani padi di Kecamatan Karangpandan sekitar 45\% masih kurang dalam menggunakan benih bersertifikat. Sehingga peneliti memilih Kecamatan Karangpandan sebagai tempat penelitian. Dari Kecamatan Karangpandan kemudian peneliti memilih dua desa sebagai objek penelitian yaitu Desa Karangpandan dan Desa Karang. Pemilihan dua desa sebagai objek penelitian didasarkan pada jauh dan dekat desa tersebut terhadap balai benih padi. Populasi dalam penelitian ini adalah semua petani yang diwakili oleh semua anggota kelompok tani yang membudidayakan tanaman padi di dua desa yaitu Desa Karangpandan dan Desa Karang, Kecamatan Karangpandan, Kabupaten Karanganyar. Penarikan sampel dalam penelitian ini dilakukan dengan menggunakan teknik multi stage cluster random sampling yaitu teknik dengan model pengelompokkan bertahap (dua 
atau lebih) dengan mengelompokkan unit analisa ke dalam gugus dimana sampel akan diambil, melalui tahap-tahap tertentu (Singarimbun dan M. Effendi, 1995). Penarikan sampel dilakukan secara acak dengan melalui kelompok pembagian cluster terendah terlebih dahulu.

Tabel 1. Petani dan Jumlah Petani Responden pada masing-masing Kelompok Tani

\begin{tabular}{cccc}
\hline No. & $\begin{array}{c}\text { Nama } \\
\text { Kelompok }\end{array}$ & $\begin{array}{c}\text { Jumlah } \\
\text { Anggota }\end{array}$ & $\begin{array}{c}\text { Jumlah } \\
\text { Sampel }\end{array}$ \\
\hline 1. & Tani Maju & 106 & 30 \\
2. & Jasa Tani & 35 & 30 \\
\hline & Jumlah & 204 & 60
\end{tabular}

Sumber: BPP Kecamatan Karangpandan, 2016

Responden dipilih menggunakan teknik acak (random) dimana pada masing-masing kelompok tani akan diacak sedemikian rupa sehingga setiap populasi akan mempunyai kemungkinan yang sama. Jenis dan sumber data yang digunakan pada penelitian ini adalah data primer dan data sekunder. Teknik pengumpulan data yang digunakan dalam penelitian ini adalah observasi, wawancara dan pencatatan. Penelitian ini menggunakan dua metode analisis data yaitu uji korelasi rank spearman dan uji beda Wilcoxon.

\section{HASIL DAN PEMBAHASAN}

\section{Gambaran Umum Benih Unggul Padi Bersertifikat}

Sertifikasi benih adalah rangkaian kegiatan penerbitan sertifikat terhadap benih yang dilakukan oleh lembaga sertifikasi melalu pemeriksaan lapangan, pengujian laboratorium dan pengawasan serta memenuhi semua persyaratan untuk diedarkan. Keunggulan benih unggul padi bersertifikat antara lain mutu benih terjamin, keseragaman benih (pertumbuhan, pembungaan dan pemasakan buah), tahan terhadap hama dan penyakit serta hasil panen benih kualitasnya terjamin. Sertifikasi benih padi di Kecamatan Karangpandan dilakukan oleh Balai Benih Padi Karangpandan.

Proses sertifikasi di Balai Benih Padi Karangpandan antara lain terdiri dari: a) mengajukan permohonan pemeriksaan lahan yang akan ditanami padi terlebih dahulu ke BPSB kemudian dari BPSB akan mengecek keadaan lahan secara langsung dilapang, b) setelah 1 bulan, pengajuan laporan fase vegetatif ke BPSB, diikuti dengan laporan fase berbunga dan fase menjelang panen, c) setelah 1,5 bulan hingga 3 bulan dari Balai Benih Padi Karangpandan akan mengajukan proses sertifikasi benih ke BPSB, serta d) setelah dua minggu dari BPSB akan memberitahukan apakah benih tersebut lolos atau tidak dalam proses sertifikasi. Jika lolos akan langsung dicetak label, jika tidak harus mengulang kembali proses sertifikasi.

Balai Benih Padi Karangpandan berperan sebagai penghasil benih unggul padi bersertifikat melalui pengawasan BPSB. Balai Benih Padi Karangpandan memiliki 4 ha luas lahan pertanian yang digunakan untuk memproduksi benih padi bersertifikat. Adapun jenis padi yang ditanami oleh Balai Benih Padi Karangpandan antara lain: sintanur (mentik), PePe, IR 64, Situ Bagendit, Mikongga, Ciherang dan Inpari.

\section{Sikap Petani Padi terhadap Benih Unggul Padi Bersertifikat}

Pengukuran sikap petani padi terhadap benih unggul padi bersertifikat dilakukan dengan mencatat jawaban responden dalam bentuk pertanyaan positif dan negatif mengenai benih unggul padi bersertifikat yang meliputi empat aspek keunggulan benih unggul padi bersertifikat antara lain mutu benih unggul padi bersertifikat, keseragaman benih unggul padi bersertifikat, ketahanan benih unggul padi bersertifikat terhadap hama dan penyakit serta hasil panen benih unggul padi bersertifikat. Responden diminta untuk memberikan respon berupa sangat setuju, setuju, netral, tidak setuju, dan sangat tidak setuju terhadap pertanyaan-pertanyaan yang diajukan kepada responden. Distribusi menurut tingkat sikap petani terhadap benih unggul padi bersertifikat dapat dilihat sebagai berikut:

Sikap petani padi terhadap mutu benih unggul padi bersertifikat di Kecamatan Karangpandan berdasarkan Tabel 2, dapat dilihat bahwa persentase terbesar tergolong dalam kategori sangat setuju sebanyak 39 orang atau sebesar $65 \%$. Hasil tersebut menunjukkan bahwa sebagian besar responden sangat setuju bahwa benih unggul padi besertifikat memiliki mutu yang baik. Responden sangat setuju bahwa benih unggul padi bersertifikat memiliki tingkat kemurinian benih yang baik, daya simpan dan kecambah yang baik, serta sifat-sifat varietas yang baik sesuai dengan yang diinginkan responden.

Sikap petani padi terhadap keseragaman benih unggul padi bersertifikat di Kecamatan 
Karangpandan berdasarkan Tabel 2, dapat dilihat bahwa persentase terbesar tergolong dalam kategori sangat setuju sebanyak 34 orang atau sebesar 56,67\%. Hasil tersebut menunjukkan bahwa sebagian besar responden sangat setuju bahwa benih unggul padi bersertifikat memiliki ukuran benih yang seragam, umur pembungaan yang seragam, umur panen yang serempak, bobot benih yang serempat serta tanaman masak dengan serempak.

Tabel 2. Distribusi Responden Berdasarkan Tingkat Sikap Petani Padi terhadap Benih Unggul Padi Bersertifikat di Kecamatan Karangpandan, Kabupaten Karanganyar

\begin{tabular}{|c|c|c|c|c|c|}
\hline \multirow{2}{*}{ No. } & \multirow{2}{*}{ Uraian } & \multirow{2}{*}{ Kategori } & \multirow{2}{*}{ Skor } & \multicolumn{2}{|c|}{ Distribusi } \\
\hline & & & & Orang & $\%$ \\
\hline \multirow[t]{6}{*}{1.} & Mutu Benih Unggul Padi & Sangat Tidak Setuju & $9,8-17,8$ & 0 & 0,00 \\
\hline & Bersertifikat & Tidak Setuju & $17,9-25,9$ & 1 & 1,67 \\
\hline & & Netral & $26-34$ & 1 & 1,67 \\
\hline & & Setuju & $34,1-42,1$ & 19 & 31,67 \\
\hline & & Sangat Setuju & $42,2-50,2$ & 39 & 65,00 \\
\hline & & Jumlah & & 60 & 100,00 \\
\hline \multirow[t]{6}{*}{2.} & Keseragaman Benih & Sangat Tidak Setuju & $9,8-17,8$ & 0 & 0,00 \\
\hline & Unggul Padi Bersertifikat & Tidak Setuju & $17,9-25,9$ & 1 & 1,67 \\
\hline & & Netral & $26-34$ & 3 & 5,00 \\
\hline & & Setuju & $34,1-42,1$ & 22 & 36,67 \\
\hline & & Sangat Setuju & $42,2-50,2$ & 34 & 56,67 \\
\hline & & Jumlah & & 60 & 100,00 \\
\hline \multirow[t]{6}{*}{3.} & Ketahanan Benih Unggul & Sangat Tidak Setuju & $9,8-17,8$ & 0 & 0,00 \\
\hline & Padi Bersertifikat terhadap & Tidak Setuju & $17,9-25,9$ & 1 & 1,67 \\
\hline & Hama dan Penyakit & Netral & $26-34$ & 4 & 6,67 \\
\hline & & Setuju & $34,1-42,1$ & 31 & 51,67 \\
\hline & & Sangat Setuju & $42,2-50,2$ & 24 & 40,00 \\
\hline & & Jumlah & & 60 & 100,00 \\
\hline \multirow[t]{6}{*}{4.} & Hasil Panen Benih Unggul & Sangat Tidak Setuju & $9,8-17,8$ & 0 & 0,00 \\
\hline & Padi Bersertifikat & Tidak Setuju & $17,9-25,9$ & 4 & 6,67 \\
\hline & & Netral & $26-34$ & 5 & 8,33 \\
\hline & & Setuju & $34,1-42,1$ & 37 & 61,67 \\
\hline & & Sangat Tidak Setuju & $42,2-50,2$ & 14 & 23,33 \\
\hline & & Jumlah & & 60 & 100,00 \\
\hline \multirow[t]{6}{*}{5.} & Sikap Petani Padi terhadap & Sangat Tidak Setuju & $39,8-71,8$ & 0 & 0,00 \\
\hline & Benih Unggul Padi & Tidak Setuju & $71,9-103,9$ & 0 & 0,00 \\
\hline & Bersertifikat & Netral & $104-136$ & 4 & 6,67 \\
\hline & & Setuju & $136,1-168,1$ & 22 & 36,67 \\
\hline & & Sangat Setuju & $168,2-200,2$ & 34 & 56,67 \\
\hline & & Jumlah & & 60 & 100,00 \\
\hline
\end{tabular}

Sumber: Analisis data primer, 2017

Sikap petani padi terhadap ketahanan benih unggul padi bersertifikat terhadap hama dan penyakit di Kecamatan Karangpandan berdasarkan Tabel 2, dapat dilihat bahwa persentase terbesar tergolong dalam kategori sangat setuju sebanyak 31 orang atau sebesar $51,67 \%$. Hasil tersebut menunjukkan bahwa responden pada penelitian setuju bahwa benih unggul padi bersertifikat memiliki tingkat ketahanan terhadap hama dan penyakit yang cukup baik. Terutama hama sundep dan penyakit hawar daun.

Sikap petani padi terhadap hasil panen benih unggul padi bersertifikat di Kecamatan Karangpandan berdasarkan Tabel 2, dapat dilihat bahwa persentase terbesar tergolong dalam kategori setuju sebanyak 37 orang atau sebesar $61,67 \%$. Hasil tersebut menunjukkan bahwa sebagian dari responden setuju bahwa benih unggul padi bersertifikat memiliki hasil panen 
baik. Sebagian responden setuju bahwa harga jual benih hasil panen benih unggul padi bersertifikat baik, hasil panen benih unggul padi bersertifikat baik, pendapatan meningkat, serta peminat beras dari hasil panen bersertifikat banyak.

Sikap petani pada terhadap benih unggul padi bersertifikat di Kecamatan Karangpandan berdasarkan Tabel 2, dapat dilihat bahwa persentase tertinggi tergolong dalam kategori sangat setuju sebanyak 34 orang atau sebesar $56,67 \%$. Responden dalam kategori setuju sebanyak 22 orang atau sebesar $36,67 \%$, sedangkan yang memiliki persentase terendah tergolong dalam kategori netral sebanyak 4 orang atau sebesar $6,67 \%$. Sikap petani terhadap benih unggul padi bersertifikat pada penelitian ini meliput: sikap petani padi terhadap mutu benih, keseragaman benih, ketahanan terhadap hama dan penyakit dan hasil panen benih. Berdasarkan data tersebut, maka dapat disimpulkan bahwa sikap petani terhadap benih unggul padi bersertifikat di Kecamatan Karangpandan dikategorikan baik atau tinggi.

\section{Faktor Pembentuk Sikap}

Diantara berbagai faktor yang mempengaruhi pembentukan sikap adalah umur, pendidikan formal, pengalaman pribadi, pengaruh orang lain yang dianggap penting, dan pengaruh media massa.

Tabel 3. Distribusi Responden Berdasarkan Faktor-Faktor yang membentuk Sikap Petani Padi terhadap Benih Unggul Padi Bersertifikat di Kecamatan Karangpandan, Kabupaten Karanganyar

\begin{tabular}{|c|c|c|c|c|c|}
\hline \multirow{2}{*}{ No. } & \multirow{2}{*}{ Uraian } & \multirow{2}{*}{ Kategori } & \multirow{2}{*}{ Skor } & \multicolumn{2}{|c|}{ Distribusi } \\
\hline & & & & Orang & $\%$ \\
\hline \multirow[t]{6}{*}{1.} & Umur & $21-31$ tahun & 1 & 0 & 0,00 \\
\hline & & $32-42$ tahun & 2 & 6 & 10,00 \\
\hline & & $43-53$ tahun & 3 & 20 & 33,33 \\
\hline & & $54-64$ tahun & 4 & 21 & 35,00 \\
\hline & & $>64$ tahun & 5 & 13 & 21,67 \\
\hline & & Jumlah & & 60 & 100,00 \\
\hline \multirow[t]{6}{*}{2.} & Pendidikan Formal & Tidak Sekolah & 1 & 2 & 3,33 \\
\hline & & SD/Tamat SD & 2 & 31 & 51,67 \\
\hline & & SLTP/Tamat SLTP & 3 & 13 & 21,67 \\
\hline & & SLTA/Tamat SLTA & 4 & 12 & 20,00 \\
\hline & & Perguruan Tinggi & 5 & 2 & 3,33 \\
\hline & & Jumlah & & 60 & 100,00 \\
\hline \multirow[t]{6}{*}{3.} & Pengalaman Pribadi & Sangat Rendah & $4,8-8,8$ & 0 & 0,00 \\
\hline & & Rendah & $8,9-12,9$ & 1 & 1,67 \\
\hline & & Sedang & $13-17$ & 29 & 48,33 \\
\hline & & Tinggi & $17,1-21,1$ & 28 & 46,67 \\
\hline & & Sangat Tinggi & $21,2-25,2$ & 2 & 3,33 \\
\hline & & Jumlah & & 60 & 100,00 \\
\hline \multirow[t]{6}{*}{4.} & Pengaruh Orang Lain yang & Sangat Rendah & $6,8-12,4$ & 0 & 0,00 \\
\hline & Dianggap Penting & Rendah & $12,5-18,1$ & 0 & 0,00 \\
\hline & & Sedang & $18,2-23,8$ & 0 & 0,00 \\
\hline & & Tinggi & $23,9-29,5$ & 15 & 25,00 \\
\hline & & Sangat Tinggi & $29,6-35,2$ & 45 & 75,00 \\
\hline & & Jumlah & & 60 & 100,00 \\
\hline \multirow[t]{6}{*}{5.} & Pengaruh Media Massa & Sangat Rendah & $4,8-8,8$ & 0 & 0,00 \\
\hline & & Rendah & $8,9-12,9$ & 8 & 13,33 \\
\hline & & Sedang & $13-17$ & 31 & 51,67 \\
\hline & & Tinggi & $17,1-21,1$ & 20 & 33,33 \\
\hline & & Sangat Tinggi & $21,2-25,2$ & 1 & 1,67 \\
\hline & & Jumlah & & 60 & 100 \\
\hline
\end{tabular}

Sumber: Analisis data primer, 2017 
1. Umur

Umur merupakan lamanya waktu hidup yang terhitung sejak lahir sampai dengan sekarang. Berdasarkan Tabel 3 diketahui bahwa persentase terbesar umur petani responden dalam penelitian ini adalah 54 sampa dengan 64 tahun, yaitu sebanyak 21 responden atau sebesar $35 \%$. Tingkat umur tersebut dapat mempengaruhi petani dalam merespon suatu informasi atau inovasi yang diterimanya. Responden pada penelitian ini sebagian besar tergolong dalam umur cukup tua, namun masih secara aktif melakukan budidaya serta terbuka dalam menerima informasi maupun inovasi yang terkait dengan budidaya pertanian.

2. Pendidikan Formal

Pendidikan formal adalah tingkat pendidikan yang ditempuh oleh responden di bangku sekolah. Berdasarkan Tabel 3 diketahui bahwa tingkat pendidikan formal petani yang memiliki persentase terbesar yaitu SD atau Tamat SD sebanyak 31 orang atau sebesar $51,67 \%$. Hasil tersebut menunjukkan bahwa tingkat pendidikan formal di Kecamatan Karangpandan tergolong dalam kategori rendah. Hal ini menunjukkan kurangnya kesadaran petani akan pentingnya pendidikan formal.

3. Pengalaman Pribadi

Pengalaman pribadi pada penelitian ini dilihat dari lamanya pengalaman responden dalam berusahatani padi, frekuensi responden mengikuti pertemuan kelompok tani, frekuensi responden mengikuti penyuluhan pertanian, serta frekuensi responden mengikuti pelatihan. Dasar pembentuk sikap satunya adaah pengalaman pribadi yang harus meninggalkan kesan yang kuat. Berdasarkan Tabel 3 diketahui bahwa pengalaman pribadi dalam penelitian jumlah terbanyak tergolong dalam kategori sedang sebanyak 29 orang atau sebesar 48,33\%. Pada penelitian ini, pengalaman pribadi terdiri dari lamanya responden berusahatani padi, frekuensi responden mengikuti pertemuan kelompok tani, frekuensi responden mengikuti penyuluhan pertanian, pendapat petani terhadap penyuluhan pertanian yang pernah diikuti dan frekuensi responden mengikuti pelatihan.

4. Pengaruh Orang Lain yang dianggap Penting

Pada penelitian ini pengaruh orang lain yang dianggap penting antara lain dilihat dari seberapa sering petani mendapatkan nasehat, mendapat dukungan pengaruh orang lain dalam pengambilan keputusan, seberapa sering petani meminta dan mengikuti masukan. Berdasarkan Tabel 3 diketahui bahwa tingkat pengaruh orang lain yang dianggap penting tergolong dalam kategori sangat tinggi sebanyak 45 orang sebesar $75 \%$. Hal ini dikarenakan orang-orang yang dianggap penting akan memberikan informasi, dukungan, saran dan pendapat kepada petani sesuai dengan yang dibutuhkan oleh petani. Orang laing yang dianggap penting dalam penelitian ini adalah penyuluh, kelompok tani, keluarga, aparat desa serta babinsa.

5. Pengaruh Media Massa

Pengaruh media massa dalam penelitian ini dilihat berdasarkan jumlah media massa yang dimanfaatkan oleh responden beserta frekuensi penggunaan media massa. Berdasarkan Tabel 3 diketahui bahwa tingkat pengaruh media massa tergolong dalam kategori sedang sebanyak 31 orang atau sebesar $51,67 \%$. Hal ini menunjukkan bahwa responden pada penelitian ini sudah cukup terbuka untuk menerima hal-hal baru yang dapat menambah pengetahuan dan informasi mereka tentang pertanian khususnya mengenai benih unggul padi bersertifikat. Media massa yang dimaksud pada penelitian ini adalah koran, radio, televisi, majalah dan internet.

\section{Hubungan Antara Faktor-Faktor Pembentuk Sikap dengan Sikap Petani Padi terhadap Benih Unggul Padi Bersertifikat}

Untuk mengetahui hubungan antara faktorfaktor pembentuk sikap dengan sikap petani diatas tersebut digunakan Uji Korelasi Rank Spearman (rs) SPSS 16.0 for windows dan untuk mengetahui tingkat signifikansi dengan membandingkan besarnya nilai $t_{\text {hitung }}$ dan $t_{\text {tabel }}$ dengan tingkat kepercayaan $95 \%(\alpha=0,05)$. 
Tabel 4. Hubungan antara Faktor-Faktor Pembentuk Sikap dengan Sikap Petani Padi terhadap Benih Unggul Padi Bersertifikat

\begin{tabular}{lrccc}
\hline \multirow{2}{*}{ Faktor Pembentuk Sikap (X) } & \multicolumn{3}{c}{ Sikap Total (Y) } & \multirow{2}{*}{ Keterangan } \\
\cline { 2 - 4 } & \multicolumn{1}{c}{$\mathrm{r}_{\mathrm{s}}$} & Sig. (2-tailed) & $\mathrm{t}_{\text {hit }}$ & \\
\hline Umur (X1) & 0,237 & 0,068 & 1,858 & Tidak signifikan \\
Pendidikan Formal (X2) & $-0,272^{*}$ & 0,035 & 2,153 & Signifikan \\
Pengalaman Pribadi (X3) & $-0,379^{* *}$ & 0,003 & 3,119 & Signifikan \\
Pengaruh Orang Lain yang Dianggap & $0,493^{* *}$ & 0,000 & 4,315 & Signifikan \\
Penting (X4) & 0,032 & 0,810 & 0,244 & Tidak Signifikan \\
Pengaruh Media Massa (X5) & & & & \\
\hline
\end{tabular}

Sumber: Analisi data primer, 2017

Keterangan:

$\mathrm{t}$ tabel : 2,685 $(\alpha=0,01)$ taraf kepercayaan $99 \%$

$\mathrm{t}$ tabel : $2.011(\alpha=0,05)$ taraf kepercayaan $95 \%$

1. Hubungan Antara Umur dengan Sikap Petani Padi dengan Benih Unggul Padi Bersertifikat

Berdasarkan Tabel 4 dapat diketahui bahwa nilai $r_{\mathrm{s}}$ sebesar 0,237 pada $\alpha=0,05$ dengan $\mathrm{t}_{\text {hitung }}$ sebesar 1,858 $<\mathrm{t}_{\text {tabel }}$ sebesar 2,011 maka $\mathrm{H}_{0}$ diterima, $\mathrm{H}_{1}$ ditolak. Artinya, tidak terdapat hubungan yang signifikan antara umur dengan sikap petani padi terhadap benih unggul padi bersertifikat di Kecamatan Karangpandan, Kabupaten Karanganyar dengan tingkat kepercayaan $95 \%$. Dapat dikatakan bahwa tua atau muda umur petani tidak mempengaruhi sikap petani terahadap benih unggul padi bersertifikat.

Hasil penelitian ini tidak sesuai dengan pendapat Soekartawi (1988) yang mengatakan bahwa semakin muda petani mempunyai semangat untuk ingin tahu apa yang mereka belum ketahui, sehingga dengan demikian mereka berusaha untuk lebih cepat melakukan perubahan terhadap inovasi baru walaupun mereka belum berpengalaman dalan inovasi tersebut. Ketidaksesuaiaan pendapat disebabkan karena pada penelitian ini baik petani muda maupun tua memiliki pendapat dan minat yang sama mengenai benih unggul padi bersertifikat.

2. Hubungan Antara Pendidikan Formal dengan Sikap Petani Padi dengan Benih Unggul Padi Bersertifikat

Berdasarkan Tabel 4 dapat diketahui bahwa nilai $r_{s}-0,272$ pada $\alpha=0,05$ dengan $t_{\text {hitung }}$ sebesar 2,153 >t tabel sebesar 2,011, maka $\mathrm{H}_{0}$ ditolak, $\mathrm{H}_{1}$ diterima. Artinya, terdapat hubungan yang signifikan antara pendidikan formal dengan sikap petani padi terhadap benih unggul padi bersertifikat di Kecamatan
* : signifikan pada $\alpha=0,05$

** : signifikan pada $\alpha=0,01$

Karangpandan, Kabupaten Karanganyar dengan tingkat kepercayaan 95\%. Hubungan kedua variabel yaitu ke arah negatif (berlawanan), sehingga semakin rendah pendidikan formal, maka semakin tinggi sikap petani terhadap benih unggul padi bersertifikat di Kecamatan Karangpandan Kabupaten Karanganyar.

Hasil penelitian ini tidak mendukung pendapat Azwar (1995), yang mengatakan bahwa lembaga pendidikan sebagai suatu sistem mempunyai pengaruh dalam pembentukan sikap yaitu meletakkan dasar pengertian dan konsep moral dalam diri individu. Pemahaman mengenai baik dan buruk, menjadi garis pemisah antara sesuatu yang tidak boleh dan boleh dilakukan, semua diperoleh dari pendidikan. Pentingnya pendidikan sebagai sarana untuk menambah ilmu pengetahuan telah mulai diperhatikan oleh petani sendiri. Pada penelitian ini responden terbanyak adalah berpendidikan SD atau tamat SD, sehingga sikap petani padi terhadap benih unggul padi bersertifikat di Kecematan Karangpandan cenderung tinggi atau baik.

3. Hubungan Antara Pengalaman Pribadi dengan Sikap Petani Padi dengan Benih Unggul Padi Bersertifikat

Berdasarkan Tabel 4 menunjukkan bahwa nilai $r_{s}-0,379$ pada $\alpha=0,01$ dengan $t_{\text {hitung }}$ sebesar 3,119 $>t_{\text {tabel }}$ sebesar 2,685, maka $\mathrm{H}_{0}$ ditolak, $\mathrm{H}_{1}$ diterima. Artinya, terdapat hubungan yang signifikan antara pengalaman pribadi dengan sikap petani padi terhadap benih unggul padi bersertifikat di Kecamatan Karangpandan, Kabupaten Karanganyar 
dengan tingkat kepercayaan 99\%. Hubungan kedua variabel yaitu ke arah negatif (berlawanan), sehingga semakin banyak/tinggi pengalaman pribadi, maka semakin rendah sikap petani terhadap benih unggul padi bersertifikat di Kecamatan Karangpandan Kabupaten Karanganyar. Pengalaman pribadi di penelitian ini berada pada kategori sedang.

Hasil penelitian ini bertolak belakang dengan pendapat Middlebrook (1974) dalam Azwar (1995) yang mengatakan bahwa tidak adanya pengalaman sama sekali dengan suatu objek cenderung akan membentuk sikap negatif terhadap objek tersebut. Sedangkan pada penelitian ini semakin tidak adanya pengalaman pribadi seseorang maka semakin tinggi sikap petani tersebut terhadap benih unggul padi bersertifikat atau membentuk sikap positif terhadap benih unggul padi bersertifikat. Dengan kata lain, semakin banyak pengalaman pribadi petani, maka semakin rendah sikap petani terhadap benih unggul padi bersertifikat atau membentuk sikap negatif terhadap benih unggul bersertifikat.

4. Hubungan Antara Pengaruh Orang Lain yang Dianggap Penting dengan Sikap Petani Padi dengan Benih Unggul Padi Bersertifikat

Berdasarkan Tabel 4 dapat diketahui bahwa nilai $r_{s}$ sebesar 0,493 pada $\alpha=0,01$ dengan $t_{\text {hitung }}$ sebesar 4,315 $>t_{\text {tabel }}$ sebesar 2,685 maka $\mathrm{H}_{0}$ ditolak, $\mathrm{H}_{1}$ diterima. Artinya, terdapat hubungan yang signifikan antara pengaruh orang lain yang dianggap penting dengan sikap petani padi terhadap benih unggul padi bersertifikat di Kecamatan Karangpandan, Kabupaten Karanganyar dengan tingkat kepercayaan $99 \%$.

Hasil penelitian sesuai dengan pendapat Azwar (1995) yaitu pada umumnya individu cenderung untuk memiliki sikap yang konformis atau searah dengan sikap orang yang dianggapnya penting. Selain itu sesuai juga dengan pendapat Zuchdi (1995) yaitu manusia cenderung bersikap sama dengan sikap orang-orang yang kita anggap penting bagi diri kita. Semakin banyak petani mendapatkan nasehat, saran dan dukungan dari orang-orang yang dianggap penting, menjadikan petani bersikap baik terhadap benih unggul padi bersertifikat yang ditunjukkan dengan minat dan kesungguhan petani menggunakan benih unggul padi bersertifikat.

5. Hubungan Antara Pengaruh Media Massa dengan Sikap Petani Padi dengan Benih Unggul Padi Bersertifikat

Berdasarkan Tabel 4 dapat diketahui bahwa nilai $r_{s}$ sebesar 0,032 pada $\alpha=0,05$ dengan $\mathrm{t}_{\text {hitung }}$ sebesar 0,244 $<\mathrm{t}_{\text {tabel }}$ sebesar 2,011 maka $\mathrm{H}_{0}$ diterima, $\mathrm{H}_{1}$ ditolak. Artinya, tidak terdapat hubungan yang signifikan antara pengaruh media massa dengan sikap petani padi terhadap benih unggul padi bersertifikat di Kecamatan Karangpandan, Kabupaten Karanganyar dengan tingkat kepercayaan $95 \%$.

Kenyataan dilapang diperkuat dengan pendapat Morissan (2010), yaitu tentang efek komunikasi, mengatakan bahwa komunikasi massa bukanlah penyebab yang diperlukan dan penyebab yang cukup bagi timbulnya sikap audien tetapi diperantarai melalu berbagai variabel lainnya. Efek terhadap audien dimediasi antara lain oleh berbagai faktor kelompok dan interpersonal dan juga oleh perilaku selektif audien. Sehingga dapat dikatakan media massa tidak berpengaruh terhadap sikap petani terhadap benih unggul padi bersertifikat. Sebagian besar petani biasanya mendapatkan informasi melalui penyuluh, kelompok tani atau petani lain

\section{Perbedaan Sikap Petani Padi terhadap Benih Unggul Padi Bersertifikat}

Perbedaan yang diteliti pada penelitian ini adalah perbedaan sikap petani padi antara petani yang jarak aksesnya dekat dengan Balai Benih Padi Kecamatan Karangpandan dengan petani yang jarak aksesnya jauh dari Balai Benih Padi Kecamatan Karangpandan. Analisis perbedaan sikap ini menggunakan uji beda Wilcoxon dengan spss 16 for windows, dengan tingkat kepercayaan $95 \%(\alpha=0,05)$.

Berdasarkan Tabel 5 menunjukkan bahwa terdapat perbedaan sikap petani padi yang signifikan terhadap benih unggul padi bersertifikat di Kecamatan Karangpandan, Kabupaten Karanganyar antara yang jarak aksesnya dekat dari Balai Benih Padi Kecamatan Karangpandan dengan petani yang jarak aksesnya jauh dengan Balai Benih Padi Kecamatan Karangpandan 
Tabel 5. Hasil Analisis Uji Beda

\begin{tabular}{lllcl}
\hline No. & $\begin{array}{c}\text { Perbedaan Sikap Petani Terhadap Benih } \\
\text { Unggul Padi Bersertifikat }\end{array}$ & $\mathbf{N}$ & Asymp. Sig (2-tailed) & $\mathbf{Z}_{\text {hit }}$ \\
\hline 1. & $\begin{array}{l}\text { Petani dengan jarak terdekat dari Balai Benih } \\
\text { Padi Kecamatan Karangpandan }\end{array}$ & 30 & & \\
2. & $\begin{array}{l}\text { Petani dengan jarak terjauh dari Balai Benih } \\
\text { Padi Kecamatan Karangpandan }\end{array}$ & 30 & 0,000 & $-4,341$ \\
\hline
\end{tabular}

Sumber: Analisis data primer, 2017

Berdasarkan Tabel 5 diatas dapat dilihat bahwa Asymp. Sig (2-tailed) sebesar 0,000 dan $Z_{\text {hit }}$ sebesar -4,341. Jika $Z_{\text {hit }}>Z_{\text {tabel }}$ yaitu 4,341 > 1,960, maka $\mathrm{H}_{0}$ ditolak, $\mathrm{H}_{1}$ diterima. Artinya terdapat perbedaan sikap yang signifikan terhadap benih unggul padi benih unggul padi bersertifikat antara petani yang jarak aksesnya jauh dari Balai Benih Padi Kecamatan Karangpandan dengan petani yang jarak aksesnya dekat dari Balai Benih Padi Kecamatan Karangpandan.

Perbedaan sikap petani padi ini berarti bahwa petani dalam menilai sesuatu objek atau informasi yang didapatkan memiliki pendapat yang berbeda. Sikap petani yang berada dekat dengan Balai Benih Padi Kecamatan Karangpandan berbeda dengan sikap petani yang berada jauh dari Balai Benih Padi Kecamatan Karangpandan. Sikap petani yang memiliki jarak akses dekat pada penelitian ini memiliki sikap yang rendah terhadap benih unggul padi bersertifikat, walaupun terbilang dekat dari Balai Benih Padi Kecamatan Karangpandan, namun pada kenyataannya petani pada Desa Karangpandan kebanyakan lebih memilih menggunakan benih unggul padi non bersertifikat atau dari hasil panen sebelumnya dibandingkan benih unggul padi non bersertifikat. Sedangkan, sikap petani yang berada jauh dari Balai Benih Padi Kecamatan Karangpandan terhadap benih unggul padi bersertifikat memiliki sikap yang tinggi. Terbukti dengan petani di Desa Karang (desa yang jarak aksesnya jauh dari balai benih Karangpandan) akan berusaha untuk menggunakan benih unggul padi bersertifikat setiap musim tanamnya dengan harapan mendapatkan hasil yang memuaskan

Sikap petani yang jaraknya dekat dengan Balai Benih Padi Karangpandan tergolong rendah. Hal ini disebabkan karena mereka menganggap bahwa meskipun benih unggul padi bersertifikat memiliki banyak keunggulan yang sudah terbukti, namun pada kenyataannya keunggulankeunggulan tersebut tidak berbeda jauh dengan benih padi unggul non bersertifikat atau dari hasil panen sebelumnya. Selain itu, alasan lainnya yang menyebabkan petani pada Desa Karangpandan tidak menggunakannya adalah karena petani sulit untuk mendapatkan benih yang digunakan karena jumlahnya yang terabatas. Ketersediaan benih unggul padi bersertifikat di Balai Benih Padi Karangpandan tidak disesuaikan dengan kebutuhan petani di Desa Karangpandan. Varietas yang di produksi tidak disesuaikan dengan varietas yang paling banyak digunakan oleh petani di Desa Karangpandan. Sehingga biasanya petani lebih memilih menggunakan benih dari hasil panen sebelumnya, daripada harus mengganti varietas jenis lain.

Sikap petani yang jaraknya jauh dengan Balai Benih Padi Karangpandan tergolong tinggi. Terbukti dengan petani di Desa Karang (desa yang jarak aksesnya jauh dari balai benih Karangpandan) akan berusaha untuk menggunakan benih unggul padi bersertifikat setiap musim tanamnya dengan harapan mendapatkan hasil yang memuaskan. Karena ketersediaan benih unggul padi bersertifikat yang terbatas. Petani di desa Karang biasanya mengganti jenis varietas padi yang ditanami yaitu disesuaikan dengan benih unggul padi bersertifikat yang tersedia di Balai Benih Karangpandan. Selain itu, petani di Desa Karang mengatakan bahwa selain dari Balai Benih Karangpandan, petani Desa Karang biasanya juga mendapatkan benih dari Balai Benih lain yang berada di Kabupaten Karanganyar seperti Balai Benih Padi yang berada di Watusambang (Tawangmangu), Jumantono, Jumapolo dan Jenawi.

\section{KESIMPULAN}

Sikap petani padi terhadap mutu benih dan keseragaman benih adalah sangat setuju. Sedangkan sikap petani terhadap ketahanan terhadap hama dan penyakit serta hasil panen benih unggul padi bersertifikat adalah setuju. 
Secara kesulurahan, sikap petani padi terhadap benih unggul padi bersertifikat adalah sangat setuju. Faktor-faktor pembentuk sikap pada penelitian ini adalah umur, pendidikan formal, pengalaman pribadi, pengaruh orang lain yang dianggap penting, dan pengaruh media massa. Hubungan antara faktor pembentuk sikap pada penelitian ini terdiri dari tidak terdapat hubungan yang signifikan antara umur dan pengaruh media massa dengan sikap petani terhadap benih unggul padi bersertifikat. Hubungan yang signifikan antara pendidikan formal dan pengalaman pribadi dengan sikap petani terhaap benih unggul padi bersertifikat, namun berlawanan arah. Hubungan signifikan yang kuat antara pengaruh orang lain yang dianggap penting dengan sikap petani padi terhadap benih unggul padi bersertifikat. Terdapat perbedaan sikap petani padi yang signifikan terhadap benih unggul padi bersertifikat di Kecamatan Karangpandan antara petani yang jaraknya dekat (Desa Karangpandan) dengan petani yang jaraknya jauh (Desa Karang) dari Balai Benih Padi Kecamatan Karangpandan. Dimana petani yang jaraknya dekat memiliki sikap yang tidak setuju dengan benih unggul padi bersertifikat. Sedangkan petani yang jaraknya jauh memikili sikap yang sangat setuju dengan benih unggul padi bersertifikat.

\section{DAFTAR PUSTAKA}

Azwar, S. 1995. Sikap Manusia: Teori dan Pengukurannya. Yogyakarta: Pustaka Pelajar.

Justice, O.L., \& Bass, L.N. 2004. Prinsip Praktek Penyimpanan Benih Diterjemahkan oleh Rennie Roesli. Jakarta: PT. Grafindo Persada.

Morissan. 2010. Psikologi Komunikasi. Bogor: Ghalia Indonesia.

Prasetyo, T., \& Setiani, C. 2011. Analisis Perkembangan Produksi dan Kebutuhan Beras di Jawa Tengah. Balai Pengkajian Teknologi Pertanian Jawa Tengah.

Singarimbun, M, \& Effendi, S. 1995. Metode Penelitian Survei, Edisi Revisi. Jakarta: PT. Pustaka LP3ES.

Sodikin, D.M. 2015. Kajian Persepsi Petani dan Produksi Penggunaan Benih bersertifikat dan Non Sertifikat Pada Usahatani Padi (Skripsi S1). Universitas Jember. Jember.

Soekartawi. 1988. Prinsip Dasar Komunikasi Pertanian. Bogor: Institut Pertanian Bogor.
Zuchdi, D, 1995. Pembentuk Sikap. Cakrawala Pendidikan. 3(14), 51-63. 